\title{
Inhibition of integrin $\beta 1-$ mediated oncogenic signalling by the antitumor microRNA-29 family in head and neck squamous cell carcinoma
}

\author{
Keiichi Koshizuka1,2, Naoko Kikkawa², Toyoyuki Hanazawa², Yasutaka Yamada ${ }^{1}$, \\ Atsushi Okato', Takayuki Arai' ${ }^{1}$, Koji Katada², Yoshitaka Okamoto² and Naohiko \\ Seki ${ }^{1}$ \\ ${ }^{1}$ Department of Functional Genomics, Chiba University Graduate School of Medicine, Chuo-ku, Chiba, Japan \\ ${ }^{2}$ Department of Otorhinolaryngology/Head and Neck Surgery, Chiba University Graduate School of Medicine, Chiba, Japan \\ Correspondence to: Naohiko Seki, email: naoseki@faculty.chiba-u.jp
}

Keywords: microRNA; miR-29a; miR-29b; miR-29c; ITGB1

Received: October 17, $2017 \quad$ Accepted: December 01, $2017 \quad$ Published: December 11, 2017

Copyright: Koshizuka et al. This is an open-access article distributed under the terms of the Creative Commons Attribution License 3.0 (CC BY 3.0), which permits unrestricted use, distribution, and reproduction in any medium, provided the original author and source are credited.

\section{ABSTRACT}

Due to their aggressive behavior, local recurrence and distant metastasis, survival rate of advanced stage of the patients with head and neck squamous cell carcinoma (HNSCC) is very poor. Currently available epidermal growth factor receptor (EGFR)-targeted therapies are not considered curative for HNSCC. Therefore, novel approaches for identification of therapeutic targets in HNSCC are needed. All members of the miRNA-29 family (miR-29a, miR-29b, and miR-29c) were downregulated in HNSCC tissues by analysis of RNA-sequencing based microRNA (miRNA) expression signature. Ectopic expression of mature miRNAs demonstrated that the miR-29 family inhibited cancer cell migration and invasion by HNSCC cell lines. Comprehensive gene expression studies and in silico database analyses were revealed that integrin $\beta 1$ (ITGB1) was regulated by the miR-29 family in HNSCC cells. Overexpression of ITGB1 was confirmed in HNSCC specimens, and high expression of ITGB1 significantly predicted poor survival in patients with HNSCC $(p=0.00463)$. Knockdown of ITGB1 significantly inhibited cancer cell migration and invasion through regulating downstream of ITGB1-mediated oncogenic signalling. In conclusion, regulation of the antitumor miR-29 family affected integrin-mediated oncogenic signalling to modulate HNSCC pathogenesis; these molecules may be novel therapeutic targets for HNSCC.

\section{INTRODUCTION}

Patients with head and neck squamous cell carcinoma (HNSCC) usually have metastatic lesions when the disease is first diagnosed, and the 5-year survival rate is less than $50 \%[1,2]$. The epidermal growth factor receptor (EGFR)-targeting monoclonal antibody cetuximab has been approved for the treatment of patients with HNSCC, the curative effects of this drug are limited $[3,4]$. Therefore, the identification of novel molecular targets in metastatic activating pathways would help to develop new therapies for this disease.

MicroRNAs (miRNAs) are small, noncoding RNAs that function to fine-tune the expression of protein-coding or protein-noncoding RNAs by sequence-dependent manner [5, 6]. Accumulating evidence has showed that aberrant expression of miRNAs disrupts systematically controlled RNA networks in cancer cells [7]. These events are deeply involved in cancer progression, metastasis, and drug resistance [8]. We have sequentially identified novel cancer pathways based on antitumor miRNAs in several cancers [9-14].

Analysis of our miRNA expression signatures based on RNA-sequencing showed that miR-29 family members (i.e., $m i R-29 a, m i R-29 b$, and $m i R-29 c$ ) are frequently detected as downregulated miRNAs in several types of cancers [10, 15-17]. Moreover, functional studies have revealed that all members of the miR-29 family inhibit cancer cell migration and invasion, suggesting that these miRNAs are involved in metastatic pathways in human 
cancers $[11,18,19]$. Our previous studies have shown that restoration of the $m i R-29$ family significantly inhibits cancer cell aggressiveness through targeting lysyl oxidase like-2 ( $L O X L 2)$ in HNSCC, renal cell carcinoma, and lung cancer [11, 20, 21]. LOXL2 functions is crosslinking of collagen and elastin in the extracellular matrix (ECM), and overexpression of LOXL2 has involved in human pathogenesis, fibrosis and cancers [22]. Knockdown of LOXL2 significantly inhibits cancer cell migration and invasion, indicating that LOXL2 could be a new therapeutic target in cancers.

In HNSCC, several studies have demonstrated the downregulation of the miR-29 family and their antitumor functions through targeting several oncogenic genes [19, 21]. We previously found that downregulation of $m i R-$ 29 family and overexpression of laminin (LAMC2) and integrin (ITGAO) in HNSCC cells, thereby activating cancer cell migration and invasion [19]. Several studies have demonstrated that activation of ECM/integrinmediated signalling contributes to cancer cell progression and metastasis [23, 24]. Thus, we hypothesised that identification of cancer networks mediated by the antitumor miR-29 family may provide novel insights into the therapeutic targets of HNSCC. In this study, we conducted re-analysis of therapeutic targets regulated by the antitumor miR-29 family in HNSCC cells and identified two key molecules, ITGA6 and ITGB1. Regulation of ITGA6 and the miR-29 family has been reported previously [19]. Thus, we focused on ITGBI and investigated the functional significance of the gene in HNSCC pathogenesis.

\section{RESULTS}

\section{Expression levels of $m i R-29$ family members in HNSCC clinical specimens and cell lines}

The expression levels of $m i R-29 a, m i R-29 b$, and $m i R-29 c$ were significantly lower in cancer tissues (n $=22$ ) and HNSCC cell lines (SAS and HSC3) than in normal epithelial tissues $(n=22)(P<0.0001, P=0.0003$, and $P<0.0001$, respectively; Supplementary Figure $1 \mathrm{~A})$.

The miR-29 family members were clustered at two different human chromosome loci ( $m i R-29 b-1$ and $m i R-29 a$ at $7 \mathrm{q} 32.3$; $m i R-29 b-2$ and $m i R-29 c$ at $1 \mathrm{q} 32.2$ ). Spearman's rank test showed positive correlations between the expression of $m i R-29 a$ and $m i R-29 b(\mathrm{R}=0.648$ and $P<0.0001)$ and between $m i R-29 b$ and $m i R-29 c(\mathrm{R}=0.746$ and $P<0.0001$; Supplementary Figure 1B).

\section{Identification of target genes regulated by the miR-29 family in HNSCC cells}

Our strategy for selection of genes regulated by the miR-29 family is shown in Figure 1. The TargetScan7.1 database showed that 1,256 genes had putative target sites for the miR-29 family in their $3^{\prime} \mathrm{UTR}$. First, to evaluate upregulated genes in clinical HNSCC specimens (accession number: GSE9638). A total of 382 genes were selected as putative targets for the $m i R-29$ family in HNSCC cells $\left(\log _{2}\right.$ ratio $\left.>0.5\right)$. Next, we performed comprehensive gene expression analyses using SAS transfectant (GEO accession number: GSE47657). Genes downregulated $\left(\log _{2}\right.$ ratio $\left.<-0.5\right)$ by transfection with $m i R-29 a$ were merged with TargetScan-selected genes. A total of 201 genes were downregulated in $m i R$ $29 a$ transfectants and had putative binding sites in their 3'UTRs, respectively.

Furthermore, we categorised these putative targets into KEGG pathways using the GeneCodis database. A total of 21 pathways were identified as $m i R-29$ family regulated pathways (Table 1). Among these pathways, we focused on the "Focal adhesion pathway" and "ECMreceptor interaction pathway" because the miR-29 family markedly inhibited cancer cell migration and invasion abilities [19]. A total of 17 genes were identified from these two pathways (Tables 2 and 3).

\section{Analysis of the clinical features of ITGB1 in patients with HNSCC using TCGA database}

We created survival curves of 17 putative target genes which were involved in "Focal adhesion pathway" and "ECM-receptor interaction pathway" using OncoLnc from TCGA database. We assessed the Kaplan-Meier univariate survival of patient groups using TCGA database; high expression of ITGA6 and ITGB1 was significantly associated with poor prognosis of patients with HNSCC (Figure 2A, Supplementary Figures 2A, 2B, and 3). The gene, COL6A6, showed the opposite behavior, its low expression was significantly associated with poor prognosis of the disease $(p=0.000993)$. Thus, we omitted it from future analysis.

We previously published several reports on ITGA6 [15, 19]; therefore, in this study, we focused on ITGBI as a target gene of the miR-29 family. Multivariate Cox proportional hazards models were used to assess independent predictors of progression-free survival. High ITGBI expression was a significant prognostic factor in patients with HNSCC (hazard ratio $[\mathrm{HR}]=1.63,95 \%$ confidence interval $[\mathrm{CI}]=1.11-2.43$, $P=0.0129$; Figure 2B).

\section{Expression of ITGB1/ITGB1 in HNSCC clinical specimens}

Expression of $I T G B 1$ was significantly upregulated in HNSCC tumor tissues $(P=0.0004$, Figures 2C). Spearman's rank test showed a negative correlation between the expression of ITGBI and miR-29a $(P=$ $0.0016, \mathrm{R}=-0.477), I T G B 1$ and $m i R-29 b(P=0.0321$, $\mathrm{R}=-0.327)$, and $I T G B 1$ and $m i R-29 c(P=0.002, \mathrm{R}=$ -0.472 ; Figure 2D). 
We also examined the expression levels of ITGB1 in HNSCC clinical specimens by immunohistochemistry. ITGB1 was strongly expressed in several cancer tissues (Figure 2E).

\section{ITGB1 was directly regulated by the $m i R-29$ family in HNSCC cells}

We also investigated whether ITGB1 expression was reduced by restoration of the miR-29 family in HNSCC cells. The mRNA and protein expression levels of ITGB1/ ITGB1 were significantly repressed in all member of miR29 family ( $m i R-29 a, m i R-29 b$ and $m i R-29 c)$ transfectants compared with that in mock transfectants (Figures 3A and 3B). The synergistic effects of $m i R-29 a, m i R-29 b$ and $m i R-29 c$ were evaluated the mRNA expression levels of $I T G B 1$ with co-transfection of $m i R-29 a, m i R-29 b$ and $m i R$ $29 c$ in SAS cells. However, no synergistic effects were observed (Supplementary Figure 4).

Furthermore, we performed luciferase reporter assays in SAS cells to determine whether ITGB1 mRNA contained target sites for the miR-29 family. We used vectors encoding the partial wild-type or deletion-type sequences of the 3'UTR of ITGB1 with miR-29 family target sites. Luminescence intensity was significantly reduced by co-transfection with the miR-29 family and the vector carrying the wild-type 3'UTR of ITGB1 mRNA (Figure 3C).

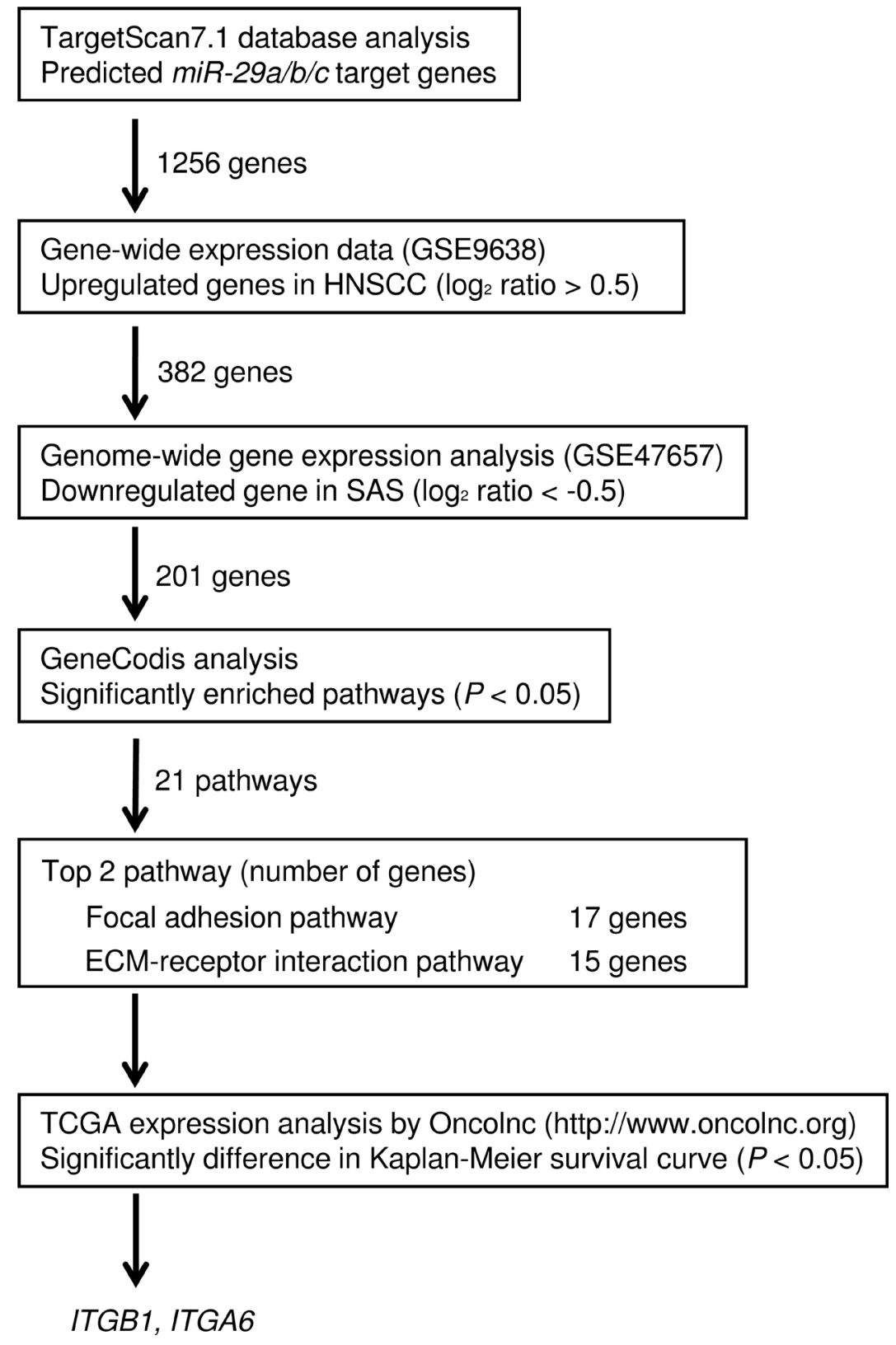

Figure 1: Flow chart depicting the strategy for identification of putative target genes regulated by the miR-29 family in HNSCC cells. 
Table 1: Significantly enriched pathways regulated by the miR-29 family in HNSCC cells

\begin{tabular}{|c|c|c|}
\hline Number of genes & Annotations & $P$-value \\
\hline 17 & (KEGG) 04510: Focal adhesion & $1.0 \mathrm{E}-13$ \\
\hline 15 & (KEGG) 04512: ECM-receptor interaction & $1.9 \mathrm{E}-16$ \\
\hline 14 & (KEGG) 04974: Protein digestion and absorption & $1.3 \mathrm{E}-15$ \\
\hline 11 & (KEGG) 05146: Amoebiasis & $5.6 \mathrm{E}-10$ \\
\hline 11 & (KEGG) 05200: Pathways in cancer & $5.9 \mathrm{E}-05$ \\
\hline 8 & (KEGG) 05222: Small cell lung cancer & $6.8 \mathrm{E}-07$ \\
\hline 6 & (KEGG) 05410: Hypertrophic cardiomyopathy (HCM) & $1.2 \mathrm{E}-04$ \\
\hline 6 & (KEGG) 04010: MAPK signaling pathway & $2.9 \mathrm{E}-02$ \\
\hline 5 & (KEGG) 05414: Dilated cardiomyopathy & $1.9 \mathrm{E}-03$ \\
\hline 5 & (KEGG) 04514: Cell adhesion molecules (CAMs) & $8.1 \mathrm{E}-03$ \\
\hline 4 & (KEGG) 04930: Type II diabetes mellitus & $1.8 \mathrm{E}-03$ \\
\hline 4 & (KEGG) 05412: Arrhythmogenic right ventricular cardiomyopathy (ARVC) & 7.7E-03 \\
\hline 4 & (KEGG) 04670: Leukocyte transendothelial migration & $3.0 \mathrm{E}-02$ \\
\hline 4 & (KEGG) 05145: Toxoplasmosis & $3.5 \mathrm{E}-02$ \\
\hline 4 & (KEGG) 04360: Axon guidance & $3.8 \mathrm{E}-02$ \\
\hline 4 & (KEGG) 04910: Insulin signaling pathway & $3.9 \mathrm{E}-02$ \\
\hline 3 & (KEGG) 00561: Glycerolipid metabolism & $2.1 \mathrm{E}-02$ \\
\hline 3 & (KEGG) 05130: Pathogenic Escherichia coli infection & $2.8 \mathrm{E}-02$ \\
\hline 3 & (KEGG) 04920: Adipocytokine signaling pathway & $3.7 \mathrm{E}-02$ \\
\hline 3 & (KEGG) 04260: Cardiac muscle contraction & 4.7E-02 \\
\hline 3 & (KEGG) 00564: Glycerophospholipid metabolism & $5.0 \mathrm{E}-02$ \\
\hline
\end{tabular}

Effects of ITGB1 knockdown on cell proliferation, migration, and invasion in HNSCC cell lines

Knockdown efficiency of si-ITGB1 transfection were evaluated in SAS and HSC3 cells, and these siRNAs effectively suppressed ITGB1/ITGB1 expression (Figure $4 \mathrm{~A}$ and $4 \mathrm{~B})$.

Cell proliferation, migration and invasion abilities were significantly inhibited in $s i-I T G B 1$ transfectants compared with that in mock transfectants (Figure 4C-4E).

\section{Effects of co-transfection with ITGB1 and the miR-29 family in SAS cells}

We performed gain-of-function analyses by ITGB1 expression vector transfection into SAS cells (Supplementary Figure 5A). Cancer cell migration and invasion abilities were enhanced by overexpression of ITGB1 in SAS cells (Supplementary Figure 5B and 5C).

To validate whether the ITGBI/miR-29 family axis was critical for the progression of HNSCC, we performed ITGBI rescue experiments by co-transfection with $I T G B 1$ and the $m i R-29$ family in SAS cells (Figure 5A). The results showed that the proliferation abilities of SAS cells were not recovered by $I T G B 1$ and $m i R-29$ family transfection compared with cells showing restoration of each $m i R-29$ family member alone (Figure 5B). In contrast, the migration and invasion abilities of SAS cells were recovered markedly by ITGBI and $m i R-29$ family transfection compared with cells showing restoration of each miR-29 family member alone (Figure $5 \mathrm{C}-5 \mathrm{~F})$. These findings suggested that $I T G B 1$ was involved in cancer cell migration and invasion in HNSCC cells.

\section{Effects of ITGB1 knockdown on downstream signalling}

We analysed the effects of downstream oncogenic signalling of ITGBI using siRNA transfection of SAS cells. The phosphorylation statuses of AKT (Ser473), ERK1/2 (Thr202/Tyr204), and FAK (Tyr397) were examined. Knockdown of ITGBI reduced the phosphorylation of AKT, ERK1/2, and FAK in SAS cells (Figure 6). We also investigated whether the expression of the miR-29 family affected downstream signalling. Restoration of the $m i R-29$ family reduced the phosphorylation of AKT, ERK1/2, and FAK in SAS cells (Figure 6).

\section{DISCUSSION}

The overall survival of patients with HNSCC recurrence or metastasis is very poor $[1,2]$. Currently 
developed EGFR inhibitors, including monoclonal antibodies and tyrosine kinase inhibitors, have achieved only modest success in the treatment of this disease $[3,4]$. Screening for novel therapeutic targets is indispensable for the development of new therapeutic strategies for patients with HNSCC recurrence or metastasis.

Our recent studies showed that antitumor miRNAs, i.e., the $m i R-29$ family, $m i R-218, m i R-150 \mathrm{~s}$, and the $m i R-$ 199 family, significantly inhibited cancer cell migration and invasion, suggesting that these miRNAs controlled metastatic genes and pathways in HNSCC cells [9, 15, $19,25]$. To date, we have shown that several ECM-related genes, including $L A M A 3, L A M B 3, L A M C 2, I T G A 3$, and $I T G A 6$, are overexpressed in HNSCC cells and that these genes are regulated by antitumor miRNAs [9, 15, 19, 25]. Laminins are heterotrimers containing $\alpha, \beta$, and $\gamma$ chains [26]. Laminin-332 (LAMA3, LAMB3, and LAMC2), a large multidomain molecule involved in cell adhesion and matrix assembly, is a prominent component of the ECM in SCC. Aberrantly expressed laminin-332 is correlated with patient prognosis in HNSCC [27, 28].

Integrins, cell adhesion molecules whose main function is to mediate mutual adhesion between cells and the ECM, e.g., laminin, collagen, elastin, and fibronectin $[29,30]$, belong to a large family of $\alpha \beta$ heterodimeric transmembrane proteins; 24 heterodimeric combinations have been reported in humans $[29,30]$. Laminin-332 can interact with two types of integrins, ITGA6/ITGB4 ( $\alpha 6 \beta 4)$ and ITGA3/ITGB1 ( $\alpha 3 \beta 1)$, and activation of laminin332-mediated integrin signalling enhances cancer cell development and metastasis [26, 31]. Our present study showed that all members of the miR-29 family directly regulated ITGBI in HNSCC cells. Moreover, ectopic expression of the miR-29 family and knockdown of $I T G B 1$ suppressed cancer cell aggressiveness by inhibiting ITGB1-mediated downstream signalling. To summarise our miRNA studies to date, laminin-332-ITGA6/ITGB4 and laminin-332-ITGA3/B1 pathways were regulated by antitumor miRNAs, i.e., the $m i R-29$ family, $m i R-218$, $m i R-150-5 p /-3 p$, and the miR-199 family, in HNSCC cells (Figure 7).

Epigenetic regulation of ITGB1 has been reported in several studies [19, 32-34]. In gastric cancer, upregulation of telomerase reverse transcriptase suppresses the expression of $m i R-29 a$ and induces the expression of ITGBI [32]. In another study, RNA sequencing demonstrated that
A

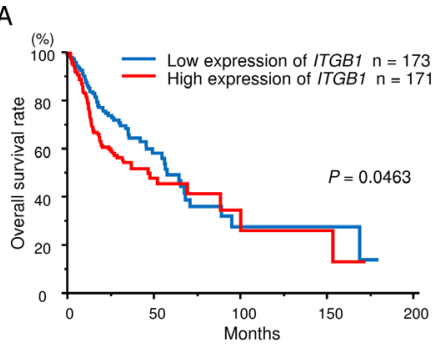

B
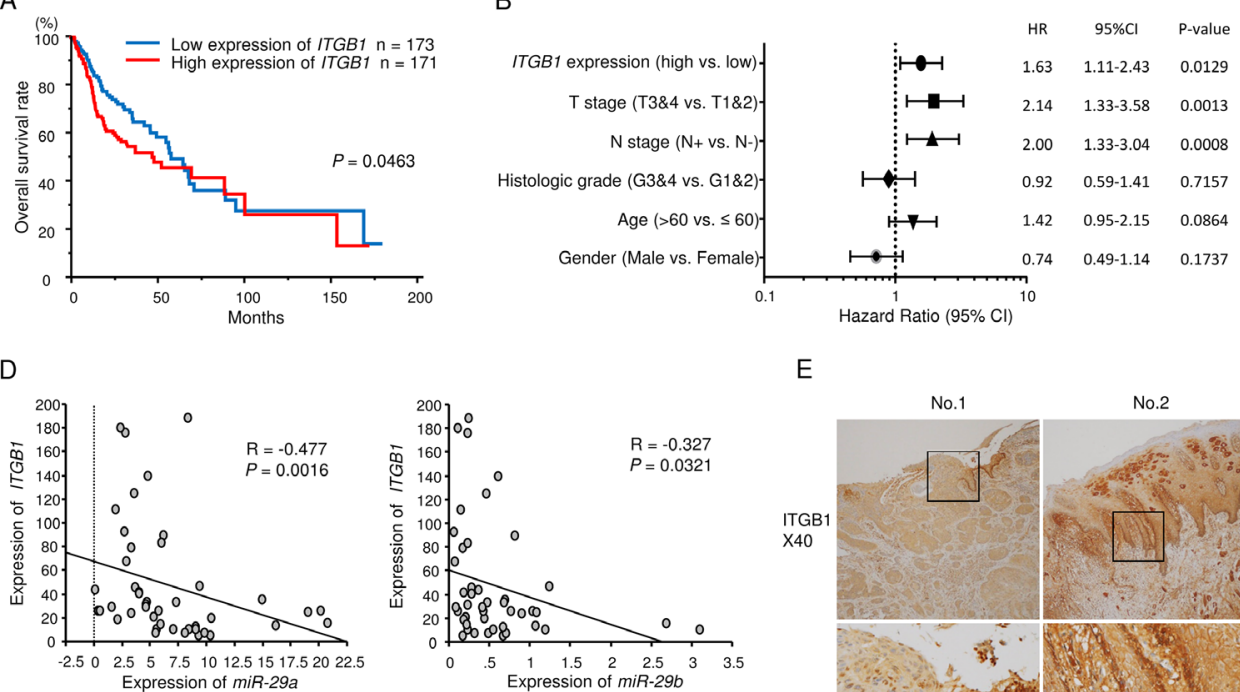

$E$

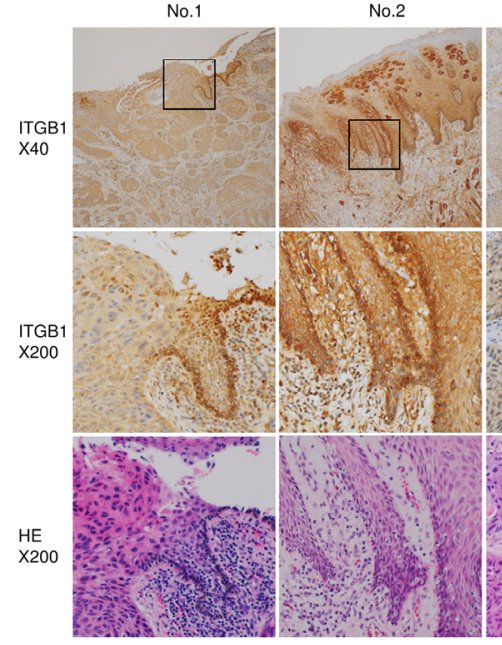

C

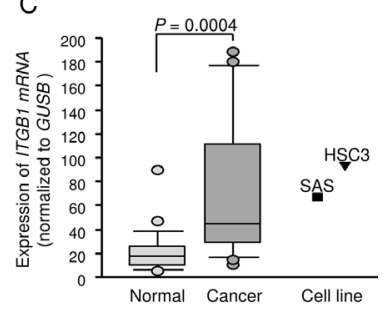

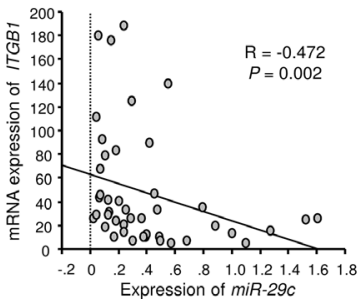

Figure 2: Expression of ITGB1 and associations between $I T G B 1$ expression levels and clinical parameters in patients with HNSCC. (A) Kaplan-Meier analysis of ITGB1 expression and overall survival. (B) Multivariate Cox proportional hazards models. (C) Expression levels of ITGB1 in HNSCC clinical specimens and cell lines. GUSB was used as an internal control. (D) The negative correlations between $I T G B 1$ expression and the expression of $m i R-29 a$, $m i R-29 b$, and $m i R-29 c$. Spearman's rank test was used to evaluate the correlation. (E) Immunohistochemical staining of ITGB1 in HNSCC clinical specimens. The patients' backgrounds and clinicopathological characteristics are summarised in Table 4. Primary rabbit anti-ITGB1 antibodies were diluted 1:100. The slides were treated with biotinylated goat anti-rabbit antibodies. ITGB1 was strongly expressed in cancer lesions (40× and $200 \times$ magnification). 
Table 2: Focal adhesion pathway-related genes in HNSCC cells

\begin{tabular}{|c|c|c|c|c|c|}
\hline Gene Symbol & Gene Name & conserved & $\begin{array}{c}\text { poorly } \\
\text { conserved }\end{array}$ & $\begin{array}{l}\text { GSE9638 } \\
\log _{2} \text { ratio }\end{array}$ & $\begin{array}{l}\text { GSE47657 } \log _{2} \\
\text { ratio }\end{array}$ \\
\hline ITGA6 & integrin, alpha 6 & 1 & 0 & 1.105 & -1.620 \\
\hline ITGBI & $\begin{array}{l}\text { integrin, beta } 1 \text { (fibronectin receptor, beta } \\
\text { polypeptide, antigen CD29 includes MDF2, } \\
\text { MSK12) }\end{array}$ & 1 & 0 & 0.708 & -0.566 \\
\hline LAMC1 & laminin, gamma 1 (formerly LAMB2) & 1 & 0 & 0.657 & -1.711 \\
\hline MAPK10 & mitogen-activated protein kinase 10 & 1 & 1 & 1.224 & -0.909 \\
\hline$P D G F R B$ & $\begin{array}{l}\text { platelet-derived growth factor receptor, beta } \\
\text { polypeptide }\end{array}$ & 1 & 0 & 0.591 & -0.738 \\
\hline COL1A2 & collagen, type I, alpha 2 & 2 & 0 & 1.854 & -0.606 \\
\hline COL3A1 & collagen, type III, alpha 1 & 2 & 0 & 2.653 & -0.782 \\
\hline COL4A1 & collagen, type IV, alpha 1 & 2 & 0 & 1.932 & -1.779 \\
\hline COL4A2 & collagen, type IV, alpha 2 & 1 & 0 & 1.792 & -1.757 \\
\hline COL4A5 & collagen, type IV, alpha 5 & 2 & 0 & 1.364 & -0.959 \\
\hline COL4A6 & collagen, type IV, alpha 6 & 1 & 0 & 3.010 & -0.870 \\
\hline COL5A1 & collagen, type V, alpha 1 & 3 & 1 & 2.438 & -1.561 \\
\hline COL5A2 & collagen, type V, alpha 2 & 2 & 0 & 2.810 & -3.182 \\
\hline COL5A3 & collagen, type V, alpha 3 & 3 & 0 & 1.373 & -0.701 \\
\hline COL6A3 & collagen, type VI, alpha 3 & 1 & 0 & 1.782 & -1.156 \\
\hline COL6A6 & collagen, type VI, alpha 6 & 1 & 0 & 1.544 & -0.741 \\
\hline COL11A1 & collagen, type XI, alpha 1 & 2 & 0 & 1.038 & -0.753 \\
\hline
\end{tabular}
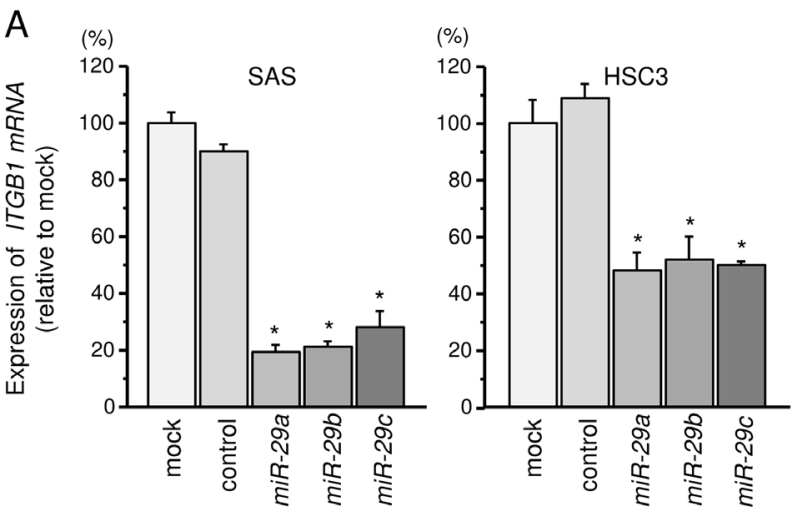

B
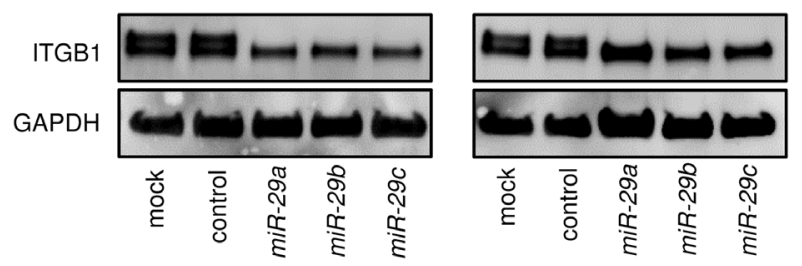

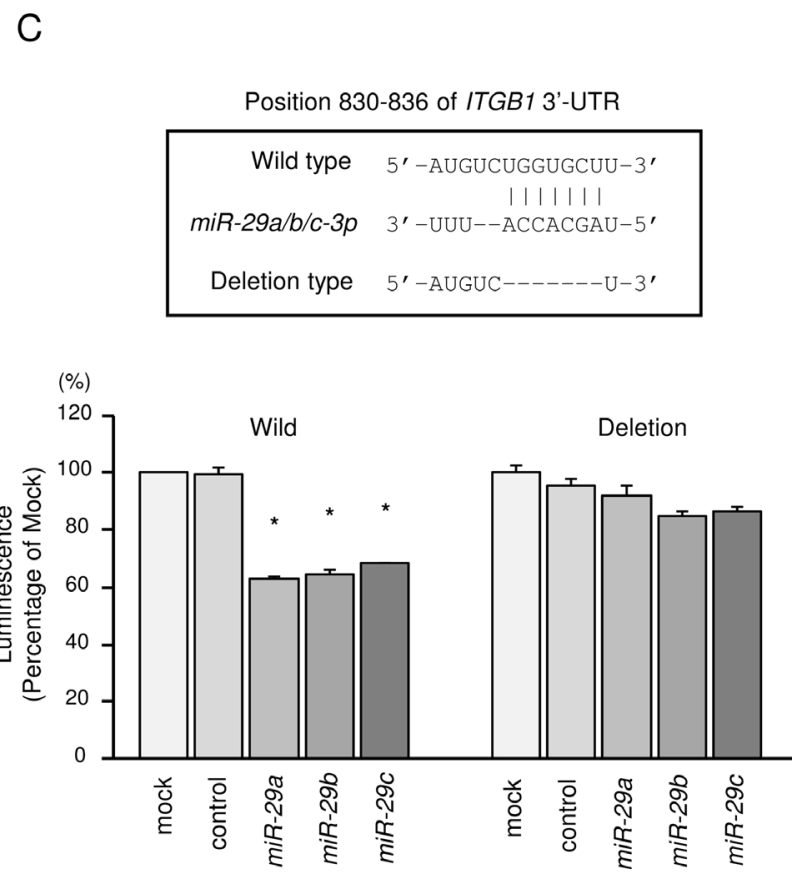

Figure 3: Regulation of ITGB1 expression by miR-29 family members in HNSCC cells. (A) Expression levels of ITGBI mRNAs $72 \mathrm{~h}$ after transfection of cells with $10 \mathrm{nM} m i R-29 a, m i R-29 b$, and $m i R-29 c$. GUSB was used as an internal control. ${ }^{*} P<0.0001$. (B) Protein expression of ITGB1 $72 \mathrm{~h}$ after transfection with $m i R-29 a, m i R-29 b$, and $m i R-29 c$. GAPDH was used as a loading control. (C) $m i R$-29 family binding sites in the 3'UTR of $I T G B 1 \mathrm{mRNA}$. Dual Luciferase reporter assays using vectors encoding putative $m i R-29$ family target sites in the ITGB1 $3^{\prime} \mathrm{UTR}$ (positions 830-836) for wild-type and deletion constructs. Normalized data were calculated as ratios of Renilla/firefly luciferase activities. ${ }^{*} P<0.0001$. 
Table 3: ECM-receptor interaction pathway-related genes in HNSCC cells

\begin{tabular}{clcccc}
\hline Gene Symbol & Gene Name & conserved & $\begin{array}{c}\text { poorly } \\
\text { conserved }\end{array}$ & $\begin{array}{c}\text { GSE9638 } \\
\log _{2} \text { ratio }\end{array}$ & $\begin{array}{c}\text { GSE47657 } \\
\mathbf{l o g}_{2} \text { ratio }\end{array}$ \\
\hline ITGA6 & integrin, alpha 6 & 1 & 0 & 1.105 & -1.620 \\
& $\begin{array}{l}\text { integrin, beta 1 (fibronectin receptor, beta } \\
\text { polypeptide, antigen CD29 includes MDF2, }\end{array}$ & 1 & 0 & 0.708 & -0.566 \\
& MSK12) & & & & \\
LAMC1 & laminin, gamma 1 (formerly LAMB2) & 1 & 0 & 0.657 & -1.711 \\
COL1A2 & collagen, type I, alpha 2 & 2 & 0 & 1.854 & -0.606 \\
COL3A1 & collagen, type III, alpha 1 & 2 & 0 & 2.653 & -0.782 \\
COL4A1 & collagen, type IV, alpha 1 & 2 & 0 & 1.932 & -1.779 \\
COL4A2 & collagen, type IV, alpha 2 & 1 & 0 & 1.792 & -1.757 \\
COL4A5 & collagen, type IV, alpha 5 & 2 & 0 & 1.364 & -0.959 \\
COL4A6 & collagen, type IV, alpha 6 & 1 & 0 & 3.010 & -0.870 \\
COL5A1 & collagen, type V, alpha 1 & 3 & 1 & 2.438 & -1.561 \\
COL5A2 & collagen, type V, alpha 2 & 2 & 0 & 2.810 & -3.182 \\
COL5A3 & collagen, type V, alpha 3 & 3 & 0 & 1.373 & -0.701 \\
COL6A3 & collagen, type VI, alpha 3 & 1 & 0 & 1.782 & -1.156 \\
COL6A6 & collagen, type VI, alpha 6 & 1 & 0 & 1.544 & -0.741 \\
COL11A1 & collagen, type XI, alpha 1 & 2 & 0 & 1.038 & -0.753 \\
\hline
\end{tabular}

$m i R-29 c$ is downregulated in gastric cancer specimens and targets $I T G B 1$ [33]. More recently, the pivotal tumor suppressor p53 was shown to induce miR-30e-5p, which targets both ITGA6 and ITGBI in colorectal cancer [35]. Our present and past studies showed that the miR-29 family directly regulates both ITGA6 and ITGBI in HNSCC cells [19]. Moreover, our recent study of the miRNA signature of HNSCC showed that the expression of miR-30e-5p was significantly reduced in HNSCC tissues [15]. These findings indicate that the miR-29 family and $m i R-30 e-5 p$ function as important regulators of cancer cell migration and invasion. We also revealed that $m i R-223$ acted as an antitumor miRNA through targeting ITGA3 and ITGBI in prostate cancer [34].

ITGB1 can form heterodimers with $\alpha$ subunits, and these heterodimers regulate numerous signalling pathways in both physiological and pathophysiological conditions [30]. Overexpression of ITGB1 was frequently observed several cancers, including HNSCC, resulting in activation of ITGB1-mediated downstream signalling pathways [32, 34-36]. Previous studies have shown that crosstalk of integrins and several growth factor receptors, such as EGFR and the hepatocyte growth factor receptor (c-Met), activated downstream signalling cooperatively [37, 38]. Overexpression and aberrant activation of EGFR signalling enhance proliferation, invasion, metastasis, and angiogenesis and are deeply involved in HNSCC aggressiveness [39, 40]. Currently, the EGFR inhibitor cetuximab has been approved for HNSCC as a first-line treatment in patients with recurrent or metastatic disease [41]. Importantly, EGFR inhibitors induced c-MET signal activation, resulting in resistance to EGFR-targeted therapy [42]. Several studies have demonstrated that activation of ITGB1-mediated signals induces radioresistance in HNSCC and breast cancer [43, 44]. Moreover, activation of ITGB1-mediated signals enhances chemoresistance in several cancers $[45,46]$. Increasing knowledge of ITGB1 suggests that aberrant expression and activation of ITGB1-mediated cancer signalling is involved in cancer cell aggressiveness. Therefore, inhibition of ITGB1 and ITGB1-mediated cancer signalling is attractive as a new treatment strategy for cancer cells that have acquired treatment resistance.

In conclusions, analysis of oncogenes targeted by the antitumor $m i R-29$ family $(m i R-29 a, m i R-29 b$, and $m i R$ $29 c$ ) showed that ITGA6 and ITGBI were directly regulated by these miRNAs in HNSCC. High expression of these oncogenic genes was associated with poor prognosis in patients with HNSCC. Inhibition of ITGBI significantly reduced cancer cell aggressiveness, indicating that ITGBI and ITGBI-mediated cancer signalling may be promising therapeutic targets for HNSCC. Identification of antitumor miRNA-mediated novel RNA networks may contribute to the development of new therapeutic strategies.

\section{MATERIALS AND METHODS}

\section{Clinical specimens of patients with HNSCC and cell lines}

The patients' backgrounds and clinicopathological characteristics are summarised in Table 4. 
Informed consent was done properly for all patients in this study. This study protocol was approved by the Institutional Review Board of Chiba University. Two human HNSCC cell lines, SAS and HSC3, were investigated in this study.

\section{Expression analyses of patients with HNSCC and cell lines}

PCR quantification was carried out essentially as previously described $[9,15]$. To quantify the expression level of miRNAs, we utilised stem-loop qRT-PCR for miR-29a (assay ID: 002112; Applied Biosystems, Foster City, CA, USA), miR-29b (assay ID: 000413), and $m i R$ -
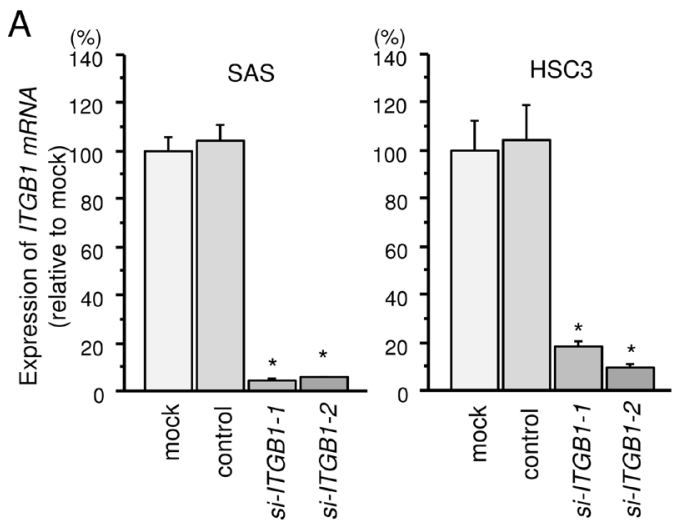

B

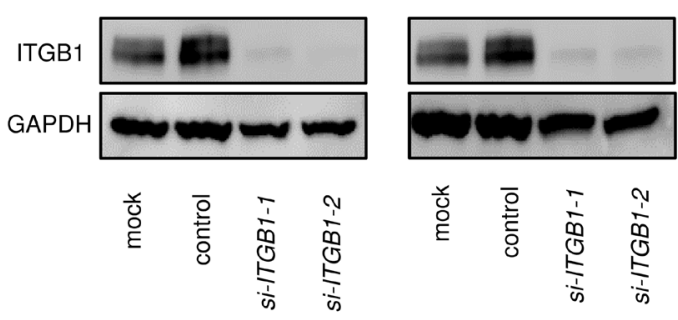

29c (assay ID: 000587) following the manufacturer's protocol. TaqMan probes and primers were used for ITGB1 expression (assay ID: Hs00559595_m1; Applied Biosystems). GUSB (assay ID: Hs99999908_m1; Applied Biosystems) and RNU48 (assay ID: 001006; Applied Biosystems) were used as internal controls.

\section{Transfection of HNSCC cell lines with miRNA mimic, small interfering RNA (siRNA), and plasmid vector}

Pre-miR miRNA precursors (miR-29a-3p; P/N: MC12499, miR-29b-3p; P/N: MC10103, $m i R-29 c-3 p ; \mathrm{P} / \mathrm{N}$ : $\mathrm{MC10518}$, and negative control miR; P/N: AM17111;
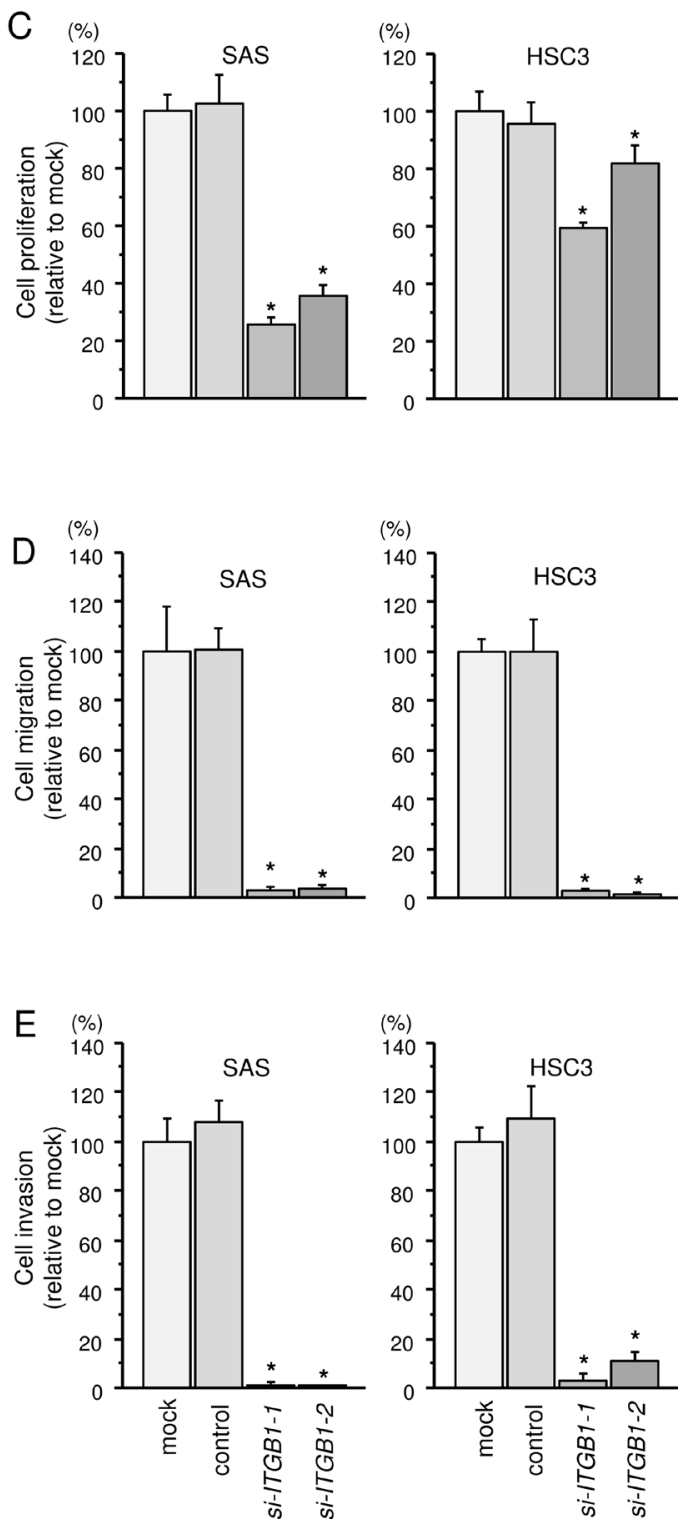

Figure 4: Effects of ITGB1 silencing by siRNA transfection in HNSCC cells. (A) ITGB1 mRNA expression 72 h after transfection of HNSCC cells with $10 \mathrm{nM}$ siRNA. GUSB was used as an internal control. ${ }^{*} P<0.0001$. (B) ITGB1 protein expression 72 $\mathrm{h}$ after transfection with siRNA. GAPDH was used as a loading control. (C) Cell proliferation was determined by XTT assays $72 \mathrm{~h}$ after transfection with siRNA. ${ }^{*} P<0.0001$. (D) Cell movement was assessed by migration assays $48 \mathrm{~h}$ after transfection with siRNA. ${ }^{*} P<$ 0.0001. (E) Characterization of invasion $48 \mathrm{~h}$ after transfection with siRNA. ${ }^{*} P<0.0001$. 
Table 4: Clinical features of 22 patients with HNSCC

\begin{tabular}{|c|c|c|c|c|c|c|c|c|c|}
\hline No. & Age & Sex & Location & $\mathbf{T}$ & $\mathbf{N}$ & $\mathbf{M}$ & Stage & Differentiaion & Remarks \\
\hline 1 & 64 & $\mathrm{~F}$ & Oral floor & $4 \mathrm{a}$ & $2 \mathrm{c}$ & 0 & IVA & moderate & $\mathrm{IHC}$ \\
\hline 2 & 73 & M & Tongue & 3 & $2 b$ & 0 & IVA & poor & $\mathrm{IHC}$ \\
\hline 3 & 77 & M & Tongue & 2 & $2 b$ & 0 & IVA & poor & \\
\hline 4 & 63 & $\mathrm{~F}$ & Oral floor & 2 & $2 b$ & 0 & IVA & Basaloid SCC & \\
\hline 5 & 59 & M & Tongue & 1 & $2 \mathrm{a}$ & 0 & IVA & moderate & \\
\hline 6 & 36 & $\mathrm{~F}$ & Tongue & 3 & 1 & 0 & III & moderate & \\
\hline 7 & 67 & M & Tongue & 3 & 0 & 0 & III & moderate & $\mathrm{IHC}$ \\
\hline 8 & 60 & $\mathrm{~F}$ & Tongue & 2 & I & 0 & III & well & \\
\hline 9 & 66 & M & Tongue & 2 & 0 & 0 & II & moderate & $\mathrm{IHC}$ \\
\hline 10 & 67 & M & Tongue & 2 & 0 & 0 & II & poor-moderate & \\
\hline 11 & 76 & $\mathrm{~F}$ & Tongue & 1 & 0 & 0 & I & well & \\
\hline 12 & 69 & M & Tongue & 1 & 0 & 0 & I & well & \\
\hline 13 & 73 & $\mathrm{~F}$ & Tongue & 1 & 0 & 0 & I & well & \\
\hline 14 & 64 & M & Tongue & 1 & 0 & 0 & I & well & \\
\hline 15 & 70 & M & Tongue & 1 & 0 & 0 & I & well & \\
\hline 16 & 38 & M & Tongue & 1 & 0 & 0 & I & well & \\
\hline 17 & 51 & M & Tongue & 1 & 0 & 0 & I & well & \\
\hline 18 & 34 & $\mathrm{~F}$ & Tongue & 1 & 0 & 0 & I & poor & \\
\hline 19 & 70 & M & Tongue & 1 & 0 & 0 & I & moderate & \\
\hline 20 & 71 & M & Tongue & 1 & 0 & 0 & I & well & \\
\hline 21 & 82 & M & Oral floor & 1 & 0 & 0 & I & well & \\
\hline 22 & 81 & $\mathrm{M}$ & Tongue & 1 & 0 & 0 & I & extremely well & \\
\hline
\end{tabular}

Applied Biosystems) were used in gain-of-function assays. si-ITGBI (P/N: HSS105559 and HSS105560; Invitrogen) was used in loss-of-function assays. Transfection procedures of RNAs or plasmid DNA were described as previously $[9,15]$.

\section{Cell proliferation, migration, and invasion assays}

Cell proliferation, migration, and invasion assays were carried out as previously described $[9,15]$.

\section{Identification of putative genes regulated by the $m i R-29$ family in HNSCC cells}

Oncogenic genes regulated by the miR-29 family were identified by a combination of in silico database analyses and gene expression analyses as described previously $[9,15]$. The microarray data were deposited into GEO database (http://www.ncbi.nlm.nih.gov/geo/; accession number: GSE47657).

\section{Western blotting}

Immunoblotting was performed with rabbit antiITGB1 antibodies (1:1000, \#9699; Cell Signaling
Technology, Danvers, MA, USA), anti-Akt antibodies (1:1000, \#4691; Cell Signaling Technology), antiphospho-Akt antibodies (1:1000, \#4060; Cell Signaling Technology), anti-extracellular signal-regulated kinase (ERK1/2) antibodies (1:1000, \#4695; Cell Signaling Technology), anti-phospho-ERK1/2 antibodies (1:2000, \#4370; Cell Signaling Technology), anti-focal adhesion kinase (FAK) antibodies (1:1000, \#3285; Cell Signaling Technology), and anti-phospho-FAK antibodies (1:1000, \#8556; Cell Signaling Technology). Anti-GAPDH antibodies (1:10000, ab8246; Abcam, Cambridge, UK) were used as an internal control.

\section{Immunohistochemistry}

Anti-ITGB1 antibodies (\#9699; Cell Signaling Technology) were used in immunohistochemistry.

\section{Plasmid construction and dual-luciferase reporter assays}

The wild-type or deletion-type sequences of the 3 '-untranslated region (UTR) of ITGBI in miR-29a, $m i R-29 b$, and $m i R-29 c$ target sites were inserted in the psiCHECK-2 vector (C8021; Promega, Madison, WI, 
USA). The procedure for dual luciferase reporter assays was described previously [9].

\section{Analysis of HNSCC specimens using The Cancer Genome Atlas (TCGA)}

HNSCC specimens in TCGA database (https:// tcga-data.nci.nih.gov/tcga/) were divided into two groups, i.e., high and low expression of ITGB1. The groups were analysed by Kaplan-Meier survival curves and log-rank statistics using OncoLnc (http://www.oncolnc. org) [47]. The genomic and clinical data were retrieved from cBioportal (http://www.cbioportal.org/), which were downloaded on May 9, 2017. Detailed information on the method is described in our previous paper [48].

\section{Statistical analysis}

Statistical analysis was performed as described previously $[9,15]$. All analyses were performed using Expert StatView
A

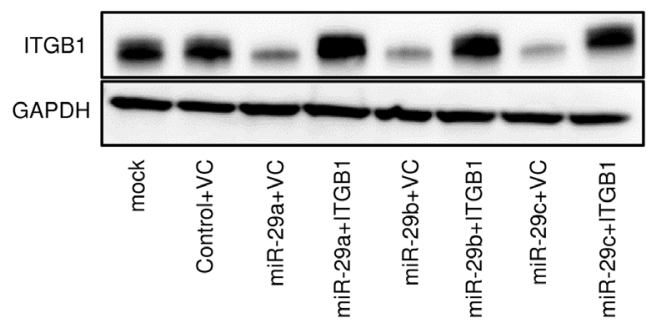

B
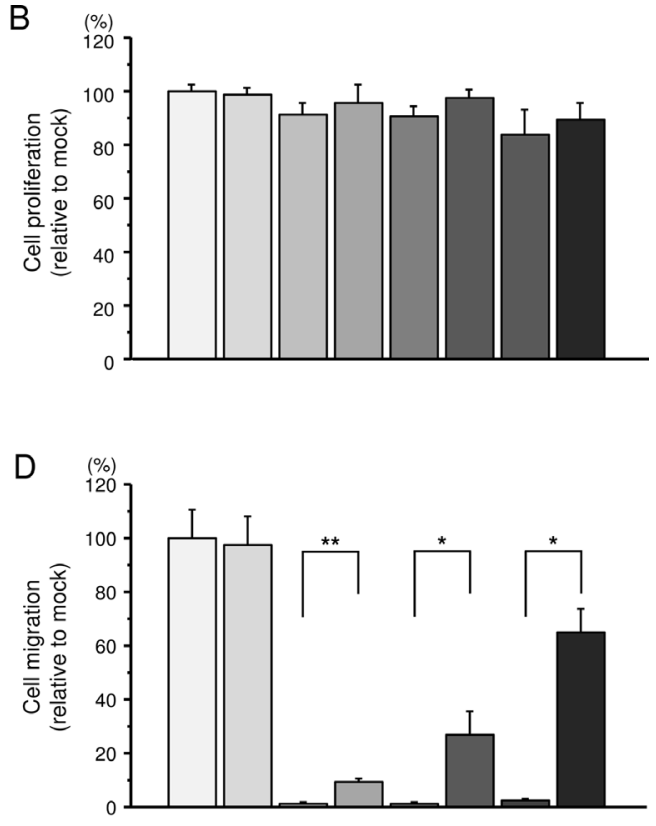

$\mathrm{F}$

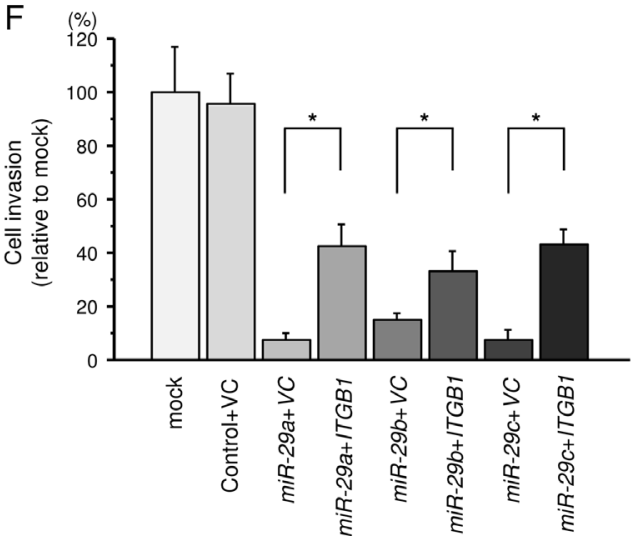

Figure 5: Effects of cotransfection with ITGB1/miR-29 family on the proliferlation, migration and invasion abilities of SAS cells. (A) Expression of ITGB1 was confirmed by western blotting $48 \mathrm{~h}$ after reverse transfection with the $m i R$ - 29 family and $24 \mathrm{~h}$ after forward transfection with the vector control $(\mathrm{VC})$ and ITGB1 expression vector $(1 \mu \mathrm{g})$ in SAS cells. GAPDH was used as a loading control. (B) Cell proliferation was determined $48 \mathrm{~h}$ after transfection with $m i R-29$ family members and $24 \mathrm{~h}$ after forward transfection with the ITGB1 expression vector $(1 \mu \mathrm{g})$. (C) Phase micrographs of SAS cells in migration assays. (100× magnification). (D) Cell migration activity was assessed $48 \mathrm{~h}$ after reverse transfection with the $m i R-29$ family and $24 \mathrm{~h}$ after forward transfection with the ITGB1 expression vector $(1 \mu \mathrm{g}) .{ }^{*} P<0.0001,{ }^{*} P<0.02$. (E) Phase micrographs of SAS cells in invasion assays. (100× magnification) (F). Cell invasion activity was assessed $48 \mathrm{~h}$ after reverse transfection with $m i R-29$ family members and $24 \mathrm{~h}$ after forward transfection with the ITGB1 expression vector $(1 \mu \mathrm{g}) .{ }^{*} P<0.0001$. 


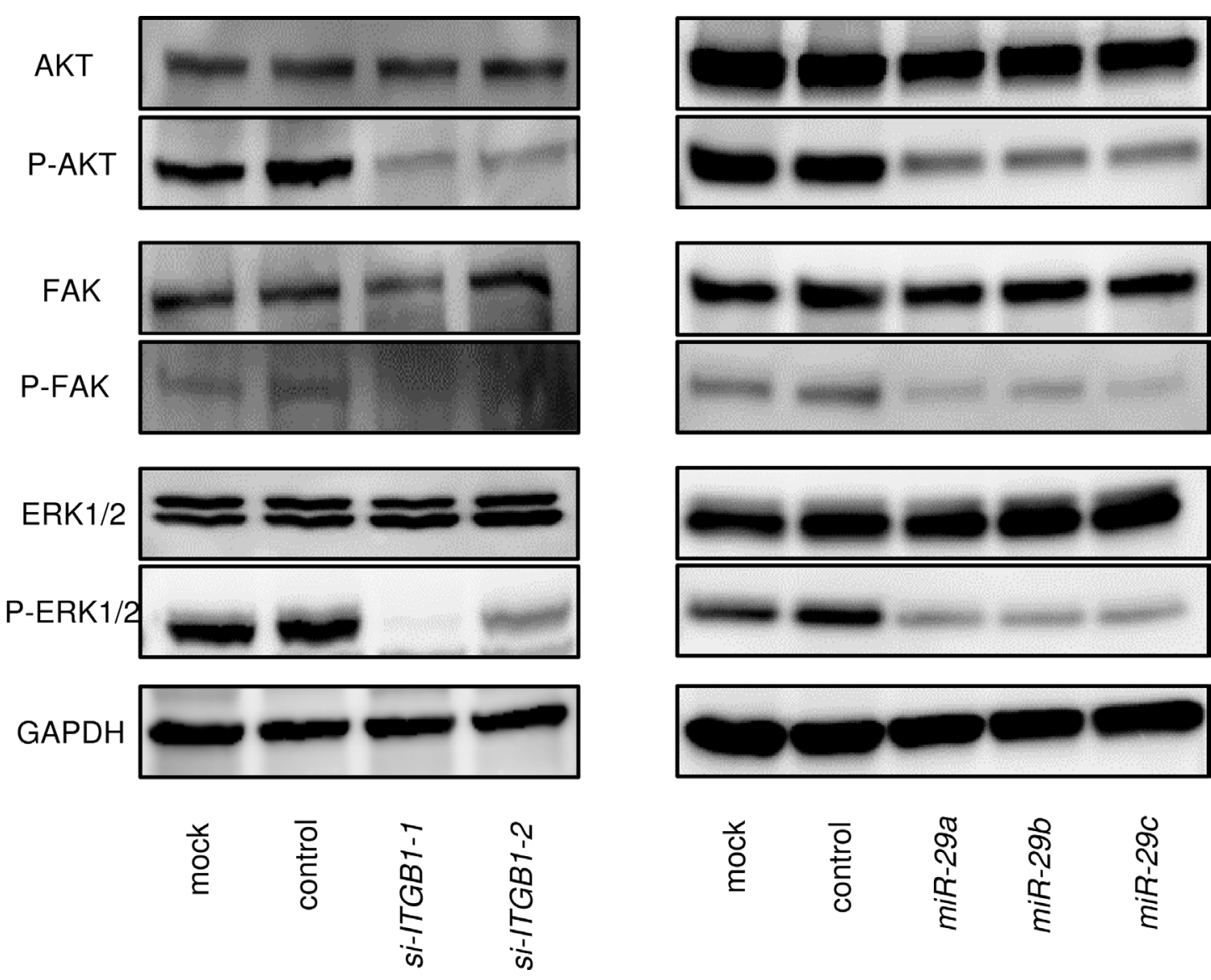

Figure 6: Effects of ITGB1-mediated downstream signalling. Knockdown of ITGB1 and restoration of the $m i R$-29 family in SAS cells reduced the phosphorylation of AKT, ERK1/2, and FAK. GAPDH was used as a loading control.
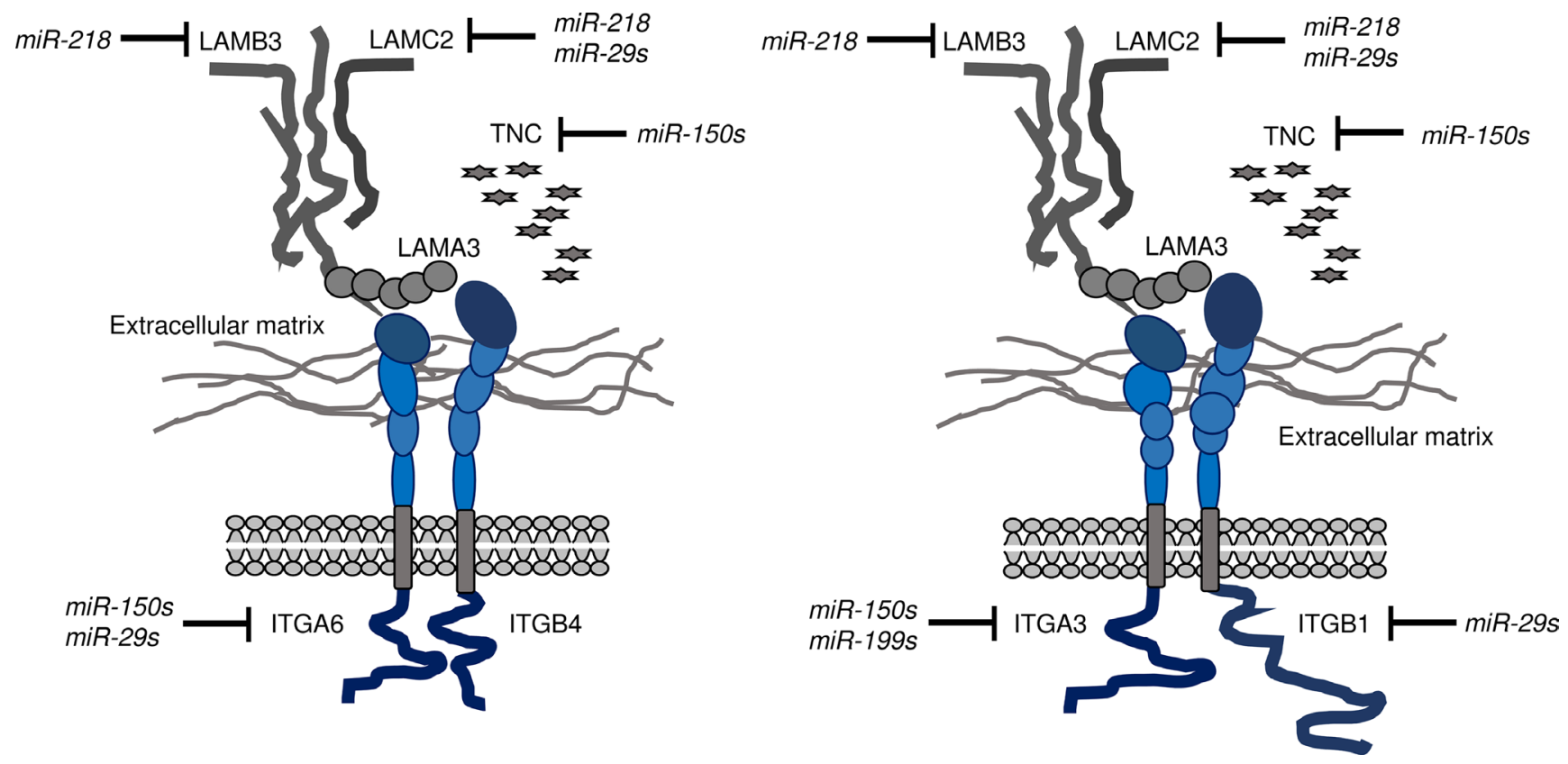

Figure 7: Illustration of inhibition of integrin receptors and ligands, i.e., laminin-332 and Tenascin C, by antitumor miRNAs in HNSCC cells. Data from our previous studies and the present study on integrins (ITGA6/ITGB4, ITGA3/ITGB1) regulated by antitumor miRNAs (the $m i R-29$ family, $m i R-218, m i R-150-5 p$, and $m i R-150-3 p$ ) and related ligands (LAMA3, LAMB3, LAMC2, and $T N C)$ are summarized. 
(version 4, SAS Institute Inc., Cary, NC, USA). Multivariate Cox proportional hazard regression models were used to determine independent factors for survival with JMP Pro 13.

\section{CONFLICTS OF INTEREST}

The authors declare no conflicts of interest.

\section{FUNDING}

This study was supported by JSPS KAKENHI(C) (grant nos. 17K16893, 16K20229, 15K10801, 16K11224, and $17 \mathrm{~K} 11375)$.

\section{REFERENCES}

1. Siegel RL, Miller KD, Jemal A. Cancer statistics, 2016. CA Cancer J Clin. 2016; 66:7-30.

2. Perez-Ordonez B, Beauchemin M, Jordan RC. Molecular biology of squamous cell carcinoma of the head and neck. J Clin Pathol. 2006; 59:445-453.

3. Bonner JA, Harari PM, Giralt J, Cohen RB, Jones CU, Sur RK, Raben D, Baselga J, Spencer SA, Zhu J, Youssoufian H, Rowinsky EK, Ang KK. Radiotherapy plus cetuximab for locoregionally advanced head and neck cancer: 5-year survival data from a phase 3 randomised trial, and relation between cetuximab-induced rash and survival. Lancet Oncol. 2010; 11:21-28.

4. Moreira J, Tobias A, O'Brien MP, Agulnik M. Targeted Therapy in Head and Neck Cancer: An Update on Current Clinical Developments in Epidermal Growth Factor Receptor-Targeted Therapy and Immunotherapies. Drugs. 2017; 77:843-857.

5. Bartel DP. MicroRNAs: genomics, biogenesis, mechanism, and function. Cell. 2004; 116:281-297.

6. Lewis BP, Burge CB, Bartel DP. Conserved seed pairing, often flanked by adenosines, indicates that thousands of human genes are microRNA targets. Cell. 2005; 120:15-20.

7. Lin S, Gregory RI. MicroRNA biogenesis pathways in cancer. Nat Rev Cancer. 2015; 15:321-333.

8. Garzon R, Marcucci G, Croce CM. Targeting microRNAs in cancer: rationale, strategies and challenges. Nat Rev Drug Disc. 2010; 9:775-789.

9. Koshizuka K, Hanazawa T, Kikkawa N, Arai T, Okato A, Kurozumi A, Kato M, Katada K, Okamoto Y, Seki N. Regulation of ITGA3 by the anti-tumor miR-199 family inhibits cancer cell migration and invasion in head and neck cancer. Cancer Sci. 2017; 108:1681-1692.

10. Goto Y, Kurozumi A, Nohata N, Kojima S, Matsushita R, Yoshino H, Yamazaki K, Ishida Y, Ichikawa T, Naya Y, Seki N. The microRNA signature of patients with sunitinib failure: regulation of UHRF1 pathways by microRNA-101 in renal cell carcinoma. Oncotarget. 2016; 7:59070-59086. https://doi.org/10.18632/oncotarget.10887.

11. Nishikawa R, Chiyomaru T, Enokida H, Inoguchi S, Ishihara T, Matsushita R, Goto Y, Fukumoto I, Nakagawa
M, Seki N. Tumour-suppressive microRNA-29s directly regulate LOXL2 expression and inhibit cancer cell migration and invasion in renal cell carcinoma. FEBS Lett. 2015; 589:2136-2145.

12. Nohata N, Sone Y, Hanazawa T, Fuse M, Kikkawa N, Yoshino H, Chiyomaru T, Kawakami K, Enokida H, Nakagawa M, Shozu M, Okamoto Y, Seki N. miR-1 as a tumor suppressive microRNA targeting TAGLN2 in head and neck squamous cell carcinoma. Oncotarget. 2011; 2:29-42. https://doi.org/10.18632/oncotarget.213.

13. Idichi T, Seki N, Kurahara H, Yonemori K, Osako Y, Arai T, Okato A, Kita Y, Arigami T, Mataki Y, Kijima Y, Maemura K, Natsugoe S. Regulation of actin-binding protein ANLN by antitumor miR-217 inhibits cancer cell aggressiveness in pancreatic ductal adenocarcinoma. Oncotarget. 2017; 8:53180-53193. https://doi.org/10.18632/oncotarget.18261.

14. Mataki H, Seki N, Mizuno K, Nohata N, Kamikawaji K, Kumamoto T, Koshizuka K, Goto Y, Inoue H. Dual-strand tumor-suppressor microRNA-145 (miR-145-5p and miR145-3p) coordinately targeted MTDH in lung squamous cell carcinoma. Oncotarget. 2016; 7:72084-72098. https://doi. org/10.18632/oncotarget.12290.

15. Koshizuka K, Nohata N, Hanazawa T, Kikkawa N, Arai T, Okato A, Fukumoto I, Katada K, Okamoto Y, Seki N. Deep sequencing-based microRNA expression signatures in head and neck squamous cell carcinoma: dual strands of pre-miR-150 as antitumor miRNAs. Oncotarget. 2017; 8:30288-30304. https://doi.org/10.18632/oncotarget.16327.

16. Itesako T, Seki N, Yoshino H, Chiyomaru T, Yamasaki T, Hidaka H, Yonezawa T, Nohata N, Kinoshita T, Nakagawa $\mathrm{M}$, Enokida H. The microRNA expression signature of bladder cancer by deep sequencing: the functional significance of the miR-195/497 cluster. PLoS One. 2014; 9:e84311.

17. Goto Y, Kojima S, Nishikawa R, Kurozumi A, Kato M, Enokida H, Matsushita R, Yamazaki K, Ishida Y, Nakagawa M, Naya Y, Ichikawa T, Seki N. MicroRNA expression signature of castration-resistant prostate cancer: the microRNA-221/222 cluster functions as a tumour suppressor and disease progression marker. $\mathrm{Br} \mathrm{J}$ Cancer. 2015; 113:1055-1065.

18. Nishikawa R, Goto Y, Kojima S, Enokida H, Chiyomaru T, Kinoshita T, Sakamoto S, Fuse M, Nakagawa M, Naya Y, Ichikawa T, Seki N. Tumor-suppressive microRNA-29s inhibit cancer cell migration and invasion via targeting LAMC1 in prostate cancer. Int J Oncol. 2014; 45:401-410.

19. Kinoshita $T$, Nohata N, Hanazawa T, Kikkawa N, Yamamoto N, Yoshino H, Itesako T, Enokida H, Nakagawa M, Okamoto Y, Seki N. Tumour-suppressive microRNA29s inhibit cancer cell migration and invasion by targeting laminin-integrin signalling in head and neck squamous cell carcinoma. Br J Cancer. 2013; 109:2636-2645.

20. Mizuno K, Seki N, Mataki H, Matsushita R, Kamikawaji K, Kumamoto T, Takagi K, Goto Y, Nishikawa R, Kato M, Enokida H, Nakagawa M, Inoue H. Tumor-suppressive 
microRNA-29 family inhibits cancer cell migration and invasion directly targeting LOXL2 in lung squamous cell carcinoma. Int J Oncol. 2016; 48:450-460.

21. Fukumoto I, Kikkawa N, Matsushita R, Kato M, Kurozumi A, Nishikawa R, Goto Y, Koshizuka K, Hanazawa T, Enokida H, Nakagawa M, Okamoto Y, Seki N. Tumorsuppressive microRNAs (miR-26a/b, miR-29a/b/c and miR218) concertedly suppressed metastasis-promoting LOXL2 in head and neck squamous cell carcinoma. J Hum Genet. 2016; 61:109-118.

22. Wu L, Zhu Y. The function and mechanisms of action of LOXL2 in cancer (Review). Int J Mol Med. 2015; 36: 1200-1204.

23. Desgrosellier JS, Cheresh DA. Integrins in cancer: biological implications and therapeutic opportunities. Nat Rev Cancer. 2010; 10:9-22.

24. Gilcrease MZ. Integrin signaling in epithelial cells. Cancer Lett. 2007; 247:1-25.

25. Kinoshita T, Hanazawa T, Nohata N, Kikkawa N, Enokida H, Yoshino H, Yamasaki T, Hidaka H, Nakagawa M, Okamoto Y, Seki N. Tumor suppressive microRNA-218 inhibits cancer cell migration and invasion through targeting laminin-332 in head and neck squamous cell carcinoma. Oncotarget. 2012; 3:1386-1400. https://doi.org/10.18632/ oncotarget.709.

26. Marinkovich MP. Tumour microenvironment: laminin 332 in squamous-cell carcinoma. Nat Rev Cancer. 2007; 7:370 380 .

27. Nakayama M, Sato Y, Okamoto M, Hirohashi S. Increased expression of laminin-5 and its prognostic significance in hypopharyngeal cancer. Laryngoscope. 2004; 114:12591263.

28. Yuen HW, Ziober AF, Gopal P, Nasrallah I, Falls EM, Meneguzzi G, Ang HQ, Ziober BL. Suppression of laminin-5 expression leads to increased motility, tumorigenicity, and invasion. Exp Cell Res. 2005; 309:198210.

29. Humphries JD, Byron A, Humphries MJ. Integrin ligands at a glance. J Cell Sci. 2006; 119:3901-3903.

30. Harburger DS, Calderwood DA. Integrin signalling at a glance. J Cell Sci. 2009; 122:159-163.

31. Ramovs V, Te Molder L, Sonnenberg A. The opposing roles of laminin-binding integrins in cancer. Matrix Biol. 2017; 57-58:213-243.

32. He B, Xiao YF, Tang B, Wu YY, Hu CJ, Xie R, Yang X, Yu ST, Dong H, Zhao XY, Li JL, Yang SM. hTERT mediates gastric cancer metastasis partially through the indirect targeting of ITGB1 by microRNA-29a. Sci Rep. 2016; $6: 21955$.

33. Moreira FC, Assumpcao M, Hamoy IG, Darnet S, Burbano R, Khayat A, Goncalves AN, Alencar DO, Cruz A, Magalhaes L, Araujo W Jr, Silva A, Santos S, et al. MiRNA expression profile for the human gastric antrum region using ultra-deep sequencing. PLoS One. 2014; 9:e92300.
34. Kurozumi A, Goto Y, Matsushita R, Fukumoto I, Kato M, Nishikawa R, Sakamoto S, Enokida H, Nakagawa M, Ichikawa T, Seki N. Tumor-suppressive microRNA-223 inhibits cancer cell migration and invasion by targeting ITGA3/ITGB1 signaling in prostate cancer. Cancer Sci. 2016; 107:84-94.

35. Laudato S, Patil N, Abba ML, Leupold JH, Benner A, Gaiser T, Marx A, Allgayer H. P53-induced miR-30e$5 \mathrm{p}$ inhibits colorectal cancer invasion and metastasis by targeting ITGA6 and ITGB1. Int J Cancer. 2017; 141: 1879-1890.

36. Ding Y, Pan Y, Liu S, Jiang F, Jiao J. Elevation of MiR9-3p suppresses the epithelial-mesenchymal transition of nasopharyngeal carcinoma cells via down-regulating FN1, ITGB1 and ITGAV. Cancer Biol Ther. 2017:1-11.

37. Carpenter BL, Chen M, Knifley T, Davis KA, Harrison SM, Stewart RL, O'Connor KL. Integrin alpha6beta4 Promotes Autocrine Epidermal Growth Factor Receptor (EGFR) Signaling to Stimulate Migration and Invasion toward Hepatocyte Growth Factor (HGF). J Biol Chem. 2015; 290:27228-27238.

38. Tesfay L, Schulz VV, Frank SB, Lamb LE, Miranti CK. Receptor tyrosine kinase Met promotes cell survival via kinase-independent maintenance of integrin alpha3beta1. Mol Biol Cell. 2016; 27:2493-2504.

39. Koshizuka K, Hanazawa T, Fukumoto I, Kikkawa N, Matsushita R, Mataki H, Mizuno K, Okamoto Y, Seki N. Dual-receptor (EGFR and c-MET) inhibition by tumorsuppressive miR-1 and miR-206 in head and neck squamous cell carcinoma. J Hum Genet. 2017; 62:113-121.

40. Kalyankrishna S, Grandis JR. Epidermal growth factor receptor biology in head and neck cancer. J Clin Oncol. 2006; 24:2666-2672.

41. Sacco AG, Cohen EE. Current Treatment Options for Recurrent or Metastatic Head and Neck Squamous Cell Carcinoma. J Clin Oncol. 2015; 33:3305-3313.

42. Bardelli A, Corso S, Bertotti A, Hobor S, Valtorta E, Siravegna G, Sartore-Bianchi A, Scala E, Cassingena A, Zecchin D, Apicella M, Migliardi G, Galimi F, et al. Amplification of the MET receptor drives resistance to anti-EGFR therapies in colorectal cancer. Cancer Disc. 2013; 3:658-673.

43. Eke I, Zscheppang K, Dickreuter E, Hickmann L, Mazzeo E, Unger K, Krause M, Cordes N. Simultaneous beta1 integrin-EGFR targeting and radiosensitization of human head and neck cancer. J Natl Cancer Inst. 2015; 107.

44. Yao ES, Zhang H, Chen YY, Lee B, Chew K, Moore $\mathrm{D}$, Park C. Increased betal integrin is associated with decreased survival in invasive breast cancer. Cancer Res. 2007; 67:659-664.

45. Ju L, Zhou C. Association of integrin betal and c-MET in mediating EGFR TKI gefitinib resistance in non-small cell lung cancer. Cancer Cell Int. 2013; 13:15.

46. Xu Z, Zou L, Ma G, Wu X, Huang F, Feng T, Li S, Lin Q, He X, Liu Z, Cao X. Integrin betal is a critical 
effector in promoting metastasis and chemo-resistance of esophageal squamous cell carcinoma. Am J Cancer Res. 2017; 7:531-542.

47. Anaya J. OncoLnc: linking TCGA survival data to mRNAs, miRNAs, and lncRNAs. Peer J Comp Sci. 2016; 2:e67.
48. Gao J, Aksoy BA, Dogrusoz U, Dresdner G, Gross B, Sumer SO, Sun Y, Jacobsen A, Sinha R, Larsson E, Cerami E, Sander C, Schultz N. Integrative analysis of complex cancer genomics and clinical profiles using the cBioPortal. Sci Signal. 2013; 6:pl1. 